Western Washington University Western CEDAR

2018

\title{
Critical Literacy in Elementary Social Studies: Juxtaposing Historical Master and Counter Narratives in Picture Books
}

Sara B. Demoiny

Jessica Ferraras-Stone

Western Washington University, Jessica.Stone@wwu.edu

Follow this and additional works at: https://cedar.wwu.edu/woodring_dei

Part of the Education Commons

\section{Recommended Citation}

Sara B. Demoiny \& Jessica Ferraras-Stone (2018) Critical Literacy in Elementary Social Studies: Juxtaposing Historical Master and Counter Narratives in Picture Books, The Social Studies, 109:2, 64-73, DOI: 10.1080/00377996.2018.1451981

This Article is brought to you for free and open access by the Woodring College of Education at Western CEDAR. It has been accepted for inclusion in Woodring Scholarship on Diversity, Equity, Inclusion by an authorized administrator of Western CEDAR. For more information, please contact westerncedar@wwu.edu. 


\title{
Critical Literacy in Elementary Social Studies: Juxtaposing Historical Master and Counter Narratives in Picture Books
}

\author{
Sara B. Demoiny ${ }^{a}$ and Jessica Ferraras-Stone ${ }^{b}$ \\ ${ }^{a}$ Department of Curriculum \& Teaching, Auburn University, Auburn, Alabama, USA; ${ }^{b}$ Western Washington University, Bellingham, \\ Washington, USA
}

\begin{abstract}
In this article the authors demonstrate how pairing master and counter narrative picture books, along with critical literacy practices, can be used to enhance the social studies curriculum outlined by state standards taught in today's elementary schools. These intentional book pairings allow students to grapple with what history truly means and to question how history is told. To facilitate an understanding of how such lessons could take place, a model lesson plan and a description of paired picture books that lend themselves to critical literacy lessons and that represent commonly taught elementary social studies content are provided. A list of resources is included to assist teachers in locating additional picture books.
\end{abstract}

\section{KEYWORDS}

Critical literacy; elementary school; social studies; picture books; counter narrative
The Cherokee assimilated to, or adopted, the ways of life of white settlers. However, the Cherokee still wanted to preserve their own culture ... In 1830, President Jackson signed a law called the Indian Removal Act ... On March 27, 1838, Van Buren sent the United States Army to force the remaining Cherokee to move west ... the Cherokee had to walk about 800 miles through bad weather ... One out of every four Cherokee died on their way to Indian Territory ... The United States also forced almost all Native Americans east of the Mississippi River off of their lands. (Berson, 2009, pp. 440-441)

This excerpt about the Trail of Tears is from a fourth-grade social studies textbook. The entire section was two pages in length told through a dominant perspective with no representation of an Indigenous voice. Most elementary school students will learn about the mistreatment of Indigenous Peoples through snippets of informational texts that simplify and sanitize historical events. One problem with this curricular and instructional pattern is that students do not hear multiple perspectives of an event, and they are only provided with mere "highlights" of events throughout history. For instance, would students learn how the Indigenous Peoples felt about the stealing of their land? Would students have any idea of the continued ways in which Indigenous Peoples were mistreated by U.S. government policy? Would they even know that many Indigenous children had to attend mandatory boarding schools that stripped them of their culture? It is crucial that our students learn about history through multiple perspectives and with a critical lens to seek a more complete understanding of our past.

As a means to assist social studies teachers with methods and resources of teaching about historical events, the authors demonstrate how paired picture books along with critical literacy practices can be used to enhance the social studies curriculum outlined by state standards taught in today's elementary schools. More specifically, the use of master narratives paired with counter narratives allow students to grapple with what history truly means and to question how history is told. To facilitate an understanding of how such lessons could take place, a detailed lesson plan and a description of paired picture books that lend themselves to critical literacy lessons and that represent commonly taught elementary social studies content are provided. In addition, a list of resources is included to assist teachers in locating additional picture books for other social studies topics.

\section{The problem with the master narrative}

Textbooks often portray history as a telling of facts about how an event occurred, and they project an 
aura of neutrality that simply does not exist (Salinas, Blevins, \& Sullivan, 2012). In fact, Loewen (2007) argued that U.S. history textbooks habitually provide a sanitized version of historical events, leaving out the complicated and contradictory policies of the U.S. government while focusing on the goal of indoctrinating patriotism in its readers. Historical figures are typically portrayed as one-dimensional heroes within the text without inclusion of the activism by everyday people around them to accomplish the battlefield win, civil rights milestones, and technological advances (Aldridge, 2006). A plethora of studies have reported the simplistic, stereotypical portrayal or complete absence of ethnic groups of color in U.S. history textbooks (Brown \& Au, 2014; Monforti \& McGlynn, 2010; Shear, 2015; Suh, An, \& Forest, 2014).

As we recognize the flaws in how history is shared in many U.S. classrooms, we must remember the telling of history is an important endeavor. It is a process that engrains into our students a narrative of our country that those in power want maintained and disseminated (Salinas et al., 2012). Social studies textbooks consistently maintain the metanarrative of U.S. history, which focuses on victory, progress, and accomplishment while silencing the atrocities, discrimination, and failures along the way (VanSledright, 2008). In most elementary teacher education programs, teacher candidates have little exposure to history content and often take only one social studies methods course. As a result, elementary school teachers frequently rely on social studies textbooks as the main source of content for their instruction (Brophy \& Alleman, 2009). For this reason there is a need for counter narratives to be present in the social studies curriculum to give a voice to those often silenced within textbooks.

Counter narratives share the experiential knowledge of those who are marginalized in U.S. history. The counter narrative challenges the stereotypic ways in which certain ethnic groups are portrayed in master narratives while providing opportunity for healing to begin as students of color learn about history through the lens of their ancestors (Ladson-Billings, 1998). Finally, counter narratives are important for White students who are accustomed to the "truth" of the master narrative. Counter narratives can encourage students to wrestle with the reality of oppression and injustice in our country's past and present (LadsonBillings, 1998 , p. 14) while considering ways to challenge oppression today.

\section{Critical literacy}

Critical literacy is a way in which students can learn to challenge the master narrative telling of U.S. history while simultaneously growing in their literacy and historical inquiry skills. McDaniel (2004) explained that "critical literacy transcends conventional notions of reading and writing to incorporate critical thinking, questioning, and transformation of self or one's world" (p. 474). Instead of simply reading a text to summarize the plot and characters, students who engage in critical literacy, begin to read and ask questions to better understand power, inequity, and injustice in human relationships.

Although there is not a singular set of critical literacy tenets agreed upon by all scholars, McDaniel (2004) described the foundational tenets of critical literacy as: (a) the uncovering of implicit messaging within the text, (b) the examination of discourse, and (c) social action. Vasquez (2010) added that critical literacy builds upon students' cultural knowledge and contends that there is a foundational understanding that texts are never neutral; they always influence readers, and that as readers, we need to reflect upon how our positions affect our interpretations of the text. Foundationally, students who read with a critical literacy lens will be able to: (a) question the intentional and implicit messages sent by the authors through the text, (b) analyze the issues of power exemplified in the text, and (c) contribute to social action that seeks equity and justice.

As a teacher, the idea of discussing issues of power and social justice with elementary school students may seem overwhelming, but elementary age students can grapple with these concepts if provided with the necessary scaffolding (Bolgatz, 2007; Gross, 2009; Husband, 2012; Souto-Manning, 2009). First, a teacher must learn about critical literacy and practice enacting this stance in her personal reading. Within the classroom, the teacher needs to introduce and model critical literacy for students and then provide multiple opportunities with a variety of texts for students to practice critical literacy in small groups and independently (McLaughlin \& DeVoogd, 2004).

A basic questioning framework for analyzing various texts through a critical literacy lens has been proposed by McLaughlin and DeVoogd (2004):

- Whose viewpoint is expressed?

- What does the author want us to think? 
- Whose voices are missing, silenced, or discounted?

- How might alternative perspectives be represented?

- How would that contribute to your understanding the text from a critical stance?

- What action might you take on the basis of what you have learned? (p. 53)

As exemplified in the model lesson plan included in this article, these proposed questions can be modified to best meet the needs of students and the topics presented in the picture books used.

\section{Critical literacy and social studies}

Social studies is the discipline charged with the responsibility to maintain the nation's democratic society by preparing students to "make informed and reasoned decisions for the public good" (National Council for the Social Studies, 1994, p. 3). Critical literacy provides social studies teachers a framework for fostering active citizenship among their students.The aforementioned tenets of critical literacy align with the purpose and goal of social studies. Critical literacy encourages students to question power and to recognize that no text is neutral. Within social studies, students must learn to work as a historian to identify the purposes and biases within primary documents. They must learn to think critically about historical and current events, learning how to take social action as a citizen.

Despite the important role social studies plays in shaping students' views of their communities and their role as active citizens, social studies continues to be given less and less instructional time in elementary school classrooms. Since the enactment of No Child Left Behind (NCLB) and its accompanying highstakes testing, social studies has been reduced to a second-class discipline, especially in elementary schools where the focus has been on reading and mathematics. Heafner and Fitchett (2012) evaluated data from the National Center for Educational Statistics regarding the weekly time allotment given to the major disciplines in elementary classrooms. After the 2007 NCLB reauthorization, elementary school teachers averaged spending only $12 \%$ of instructional time each week teaching social studies.

In light of the fact that teachers today are required to focus on the core subjects, English Language Arts (ELA) and Mathematics, it is clear that social studies has been downgraded to an optional or enrichment discipline within most elementary schools. Yet through the use of critical literacy, it is possible for teachers to address ELA topics, such as point of view and reading comprehension, through the use of picture books focused upon historical content; therefore, allowing teachers to utilize allotted ELA instructional time to teach ELA and social studies in tandem with one another. Literacy skills can be used as a vehicle for students to engage with social studies content.

\section{C3 Framework}

The National Council for the Social Studies developed the College, Career, and Civic Life framework (C3 Framework) in response to the adoption and/or modification of the Common Core State Standards. States use the C3 Framework, along with the national standards, as a guide to develop their social studies state standards. The C3 Framework focuses upon the social studies skills, concepts, and disciplinary tools that students should learn to be successful in adult life (NCSS, 2013). It has four main dimensions: (a) Developing questions and planning inquiries; (b) Applying disciplinary concepts and tools; (c) Evaluating sources and using evidence; (d) Communicating conclusions and taking informed action.

In many ways, critical literacy is a framework that can be used to teach the $\mathrm{C} 3$ dimensions required in social studies. This article promotes the implementation of the C3 Framework through critical literacy lessons. Table 1 illustrates how the C3 Framework and critical literacy can be used synergistically to aid students in becoming informed readers who think critically about the texts they read and to encourage students to take social action as they are becoming active citizens in a democratic society. The table also describes how the following model lesson represents each C3 dimension.

\section{Use of picture books}

Multiple perspectives and critical literacy may be included through a variety of materials within social studies lessons; however, the use of pictures has particular benefits for students. One benefit that should not be overlooked is student engagement. Owens and Nowell (2001), when writing about picture books in social studies explicitly state, "Anyone who has recently spent time in elementary school classrooms has heard children pleading for more when their teachers use children's literature" (p. 33). Fuhler 
Table 1. Pairing C3 Framework with Critical Literacy.

\begin{tabular}{|c|c|c|}
\hline C3 Framework Dimensions & Critical Literacy Practices & C3 Alignment in Model Lesson Plan \\
\hline $\begin{array}{l}\text { Dimension 1: Developing Questions } \\
\text { \& Planning Inquiries }\end{array}$ & $\begin{array}{l}\text { Teachers develop questions about perspective, power, and } \\
\text { justice. }\end{array}$ & $\begin{array}{l}\text { Teachers use a series of critical questions to prompt } \\
\text { investigation of perspectives. After the reading of } \\
\text { each picture book, students have the opportunity to } \\
\text { generate more questions, which could lead to an } \\
\text { extended research inquiry. }\end{array}$ \\
\hline $\begin{array}{l}\text { Dimension 2: Applying Disciplinary } \\
\text { Tools \& Concepts }\end{array}$ & $\begin{array}{l}\text { Critical literacy picture book content may focus upon a } \\
\text { historical event, a civic action, a geographic location, and/ } \\
\text { or effects of the economy }\end{array}$ & $\begin{array}{l}\text { Students explore and critique different perspectives on } \\
\text { the treatment of Indigenous Peoples. Perspectives is } \\
\text { one indicator of a disciplinary tool within History. }\end{array}$ \\
\hline $\begin{array}{l}\text { Dimension 3: Evaluating Sources \& } \\
\text { Using Evidence }\end{array}$ & $\begin{array}{l}\text { Students will be able to seek multiple perspectives from } \\
\text { various books, including critical literacy picture books }\end{array}$ & $\begin{array}{l}\text { Students compare master and counter narrative picture } \\
\text { books to critically analyze the mistreatment of } \\
\text { Indigenous Peoples in the U.S. }\end{array}$ \\
\hline $\begin{array}{l}\text { Dimension 4: Communicating } \\
\text { Conclusions \& Taking Informed } \\
\text { Actions }\end{array}$ & $\begin{array}{l}\text { Students will respond to the picture book readings, through } \\
\text { reflection, discussion, journaling, and social justice projects }\end{array}$ & $\begin{array}{l}\text { Students write a letter to textbook editors asking for the } \\
\text { inclusion of Indigenous perspectives on the many } \\
\text { ways in which they have experienced discrimination } \\
\text { (and still do). }\end{array}$ \\
\hline
\end{tabular}

(1992) illustrates this point quoting a young adolescent student who was emotional after reading Faithful Elephants (Tsuchiya, 1988) as part of a World War II unit. When asked if he saw value to reading the picture book, the student replied, "Yeah, because you know what else happened in the war than just what happened when the bomb was dropped" (Fuhler, 1992, p. 177). This student response conveys both a student engaged with the topic and one that is appreciative of the details provided by the picture book that enhance his understanding of the historical time period.

Picture books synergistically use "both text and illustration to create meaning; one is not as powerful alone as it is with the other" (Giorgis, 1999, p. 51). Therefore, isolated attention to the text in picture books limits their power. To utilize picture books to their fullest potential, an emphasis should also be placed on visual literacy - the ability to make meaning and gather information from images (Rowsell, McLean, \& Hamilton, 2012). As O’Neil (2011) asserts, visual imagery in picture books, even at a cursory glance, convey the time and place of historical events with more description than is often attended to in books. To capitalize on the synergistic relationship between text and images in picture books, Rowsell, McLean, and Hamilton (2012) recommend the following questions: (a) What is the relationship between the image and text? (b) What information is in the image that is not in the text? and (c) What information is in the text that is not in the image?

While the images in picture books serve as vehicles to convey important content, their benefits extend beyond providing details. Pictures can improve comprehension that facilitates both short- term and long-term recall (Carney \& Levin, 2002; Hibbing \& Rankin-Erickson, 2003). The rich illustrations in picture books, through their careful use of images and color, guide readers how to feel, thus connecting the reader with the characters (Wolf, 2003). Moreover, picture books have the "potential to act as a magnifying glass that enlarges and enhances the reader's personal interactions with a subject" (Vacca \& Vacca, 2005, p. 161). This connection between the reader and the characters is especially important when analyzing issues of power, as is the aim with critical literacy lessons, because it de-neutralizes the text by placing the reader within the context of the story. And, in the case of counter narratives, this connection can help the reader understand the oppression felt by those whose voices have often been silenced or marginalized. Denaturalized discussions around topics of power and oppression may cause elementary school teachers discomfort, yet picture books may provide a comfortable distance, and hence, a safe medium by which to begin such discussions. As Glenn (2006) explains, adding a comfortable distance, such as the use of supplemental literature, between the reader and "hot topics" can reduce the emotional risk in the classroom. In sum, picture books provide a rich domain for developing critical readers that analyze both text and images for meaning (Painter, Martin, \& Unsworth, 2013).

For such benefits to manifest themselves in the social studies lessons, teachers must exercise diligence when selecting picture books. Mendoza and Reese (2001) caution that many picture books present stories with historical inaccuracies and, therefore, should be avoided. Beyond historical accuracy, Meller, 
Richardson, and Hatch (2009) offered the following criteria to help teachers select picture books that work best for critical literacy lessons. The picture books should:

- Explore differences rather than make them invisible.

- Enrich understandings of history and life by giving voice to those traditionally silenced or marginalized.

- Show how people can begin to take action on important social issues.

- Explore dominant systems of meaning that operate in our society to position people and groups of people as "others".

- Don't provide "happily ever after" endings for complex social problems (p. 77).

Although a teacher may know the criteria for selecting an appropriate picture book for a critical literacy social studies lesson, it may be difficult to know where to begin looking for books. Table 2 lists resources teachers may use to find picture books that often meet the selection criteria.

\section{Critical literacy example lesson plan}

In this section the authors have developed a model lesson outline demonstrating how to juxtapose a master and counter narrative in U.S. history using picture books. The lesson outline does not dictate the exact steps teachers must take; instead, it gives teachers an idea of how to incorporate critical literacy questions within their lesson plans. Because this is a model lesson outline that can be adapted across grade levels, specific standards and curriculum have not been listed, yet the selected content is often included in upper elementary social studies standards. The authors encourage teachers to make professional decisions regarding the length of this lesson/unit, the facilitation of questions (whole group, small group, individual), and the types of assessment used.

The model lesson below may take place after students have investigated the mistreatment of Indigenous Peoples in their social studies textbook. Most textbooks, for a variety of reasons ranging from space limitations to political agendas, dedicate few pages to the years of Indigenous Peoples' mistreatment in the past and continued into the present. To aid students in gaining a deeper understanding of the elapsed time and repeated injustices against Indigenous Peoples, teachers can consider utilizing picture books that represent the master narrative, such as Forced Removal (Schwartz, 2015) and a counter narrative, like Shin-Chi's Canoe (Campbell, 2008). It is important to note that, because of time constraints, teachers may choose to read only sections of the picture book. In either respect, the authors recommend that teachers plan the critical questions prior to the lesson. The following model lesson outline in Figure 1 provides critical questions that could be used for each component of a typical read aloud lesson plan. Teachers also may want to build their background knowledge of Native American boarding schools. Below are a few websites that would provide further investigation for teachers and students:

- When Will U.S. Apologize for Boarding School Genocide? - http://indiancountrytodaymedia network.com/2015/06/19/when-will-us-apolo gize-boarding-school-genocide- 160797

- Does a Silent Apology Really Say "We're Sorry"? - http://indiancountrytodaymedianetwork.com/ 2011/12/03/does-silent-apology-really-say-weresorry

- A Long-Awaited Apology for Residential Schools - http://www.cbc.ca/archives/entry/a-long-awaitedapology-for-residential-schools

Table 2. Picture Book Resources.

\begin{tabular}{|c|c|}
\hline Book Organization & Website Addresses \\
\hline American Library Association & http://www.ala.org/awardsgrants/notable-childrens-books \\
\hline Association for Library Service to Children & http://www.ala.org/alsc/awardsgrants/bookmedia/belpremedal \\
\hline Carter G. Woodson Book Award & http://www.socialstudies.org/awards/woodson/winners \\
\hline Children's Book Council & http://www.cbcbooks.org/notable-social-studies/ \\
\hline Coretta Scott King Book Award & http://www.ala.org/emiert/coretta-scott-king-book-awards-all-recipients-1970-present \\
\hline Database of Award-Winning Children's Literature & http://www.dawcl.com/ \\
\hline International Reading Association & https://www.literacyworldwide.org/get-resources/reading-lists \\
\hline National Council for the Social Studies Notable Books & http://www.socialstudies.org/resources/notable \\
\hline Pura Belpré Book Award & http://www.ala.org/alsc/awardsgrants/bookmedia/belpremedal \\
\hline Reading Rockets & http://www.readingrockets.org/books/booksbytheme \\
\hline University of Delaware & http://www1.udel.edu/dssep/literature.html \\
\hline
\end{tabular}




\begin{tabular}{|c|c|}
\hline Master Narrative & Counter Narrative \\
\hline \multicolumn{2}{|c|}{ Picture Book } \\
\hline $\begin{array}{l}\text { Forced Removal (Schwartz, 2015) } \\
\text { This book outlines four causes and three effects of the Trail of Tears. } \\
\text { To this point, "Indigenous Peoples" has been used throughout the } \\
\text { text; however, in this figure, the authors use "Native Americans" } \\
\text { instead because this was the term used within the picture book. }\end{array}$ & $\begin{array}{l}\text { Shin-Chi's Canoe (Campbell, 2008) } \\
\text { This book tells the story of Shin-Chi's experiences in a } \\
\text { Canadian Indian residential schools, which also occurred in } \\
\text { the United States. }\end{array}$ \\
\hline \multicolumn{2}{|c|}{ Activating students' prior knowledge } \\
\hline $\begin{array}{l}\text { What did our textbook teach us about Native Americans and White } \\
\text { Americans living together? }\end{array}$ & $\begin{array}{l}\text { What did our textbook teach us about our nation's treatment } \\
\text { of Native Americans? }\end{array}$ \\
\hline \multirow{2}{*}{$\begin{array}{l}\text { What else do you want to learn about the way Native Americans and } \\
\text { White Americans interacted? }\end{array}$} & What new information did we learn from Forced Removal? \\
\hline & Have Native Americans been mistreated in other ways? \\
\hline \multicolumn{2}{|c|}{ Book preview } \\
\hline What new information do you think this book can help us learn? & $\begin{array}{l}\text { Who do you think is going to tell us the story? Do you think } \\
\text { that will influence how the story is told? }\end{array}$ \\
\hline \multirow{2}{*}{$\begin{array}{l}\text { Who do you think is going to tell us the story? Do you think that } \\
\text { will influence how the story is told? }\end{array}$} & $\begin{array}{l}\text { What do you think the story is going to be about? (after } \\
\text { reviewing the pictures) }\end{array}$ \\
\hline & $\begin{array}{l}\text { After telling the students that the book is about the schools } \\
\text { Native Americans attended, ask the students if they have any } \\
\text { predictions about these schools. }\end{array}$ \\
\hline \multicolumn{2}{|c|}{ Read aloud } \\
\hline \multirow{4}{*}{$\begin{array}{l}\text { P. } 4 \text { "White Americans and American Indians shared land in the } \\
\text { New World for centuries. Over several hundred years they'd } \\
\text { learned to live together in settled states east of the Mississippi } \\
\text { River". } \\
\text { What do you think the White Americans meant by "learning to } \\
\text { live" with the Native Americans? What do you think Native }\end{array}$} & $\begin{array}{l}\text { Why did the Native American children have to leave their } \\
\text { home? }\end{array}$ \\
\hline & Why do you think the children rode in a cattle truck? \\
\hline & $\begin{array}{l}\text { Why do you think the school personnel cut Shi-shi-etko's } \\
\text { hair? }\end{array}$ \\
\hline & $\begin{array}{l}\text { Why do you think Shin-Chi feels old enough to have his } \\
\text { own canoe? }\end{array}$ \\
\hline $\begin{array}{l}\text { P. } 6 \text { "The U.S. government wanted Indians to fit in better by } \\
\text { behaving more like White Americans." } \\
\text { What do you think the Native Americans wanted? } \\
\text { Why do you think the U.S. government wanted the Native } \\
\text { Americans to be like them? }\end{array}$ & $\begin{array}{l}\text { Who do you think wrote the law that Sh-shi-etko's mother } \\
\text { refers to? ("If we could, we would keep you here at } \\
\text { home. We would never, ever let you go, but it's the law".) }\end{array}$ \\
\hline \multicolumn{2}{|l|}{$\begin{array}{ll}\text { Closure/Summary } \\
\end{array}$} \\
\hline $\begin{array}{l}\text { How is this story different than our textbook? What new } \\
\text { information did we learn? }\end{array}$ & Who is telling the story? \\
\hline $\begin{array}{l}\text { How do you think a White American living in this time period } \\
\text { would tell us the story of the Trail of Tears? }\end{array}$ & Based on this account, what new questions do you have? \\
\hline $\begin{array}{l}\text { How do you think a Native American living in this time period } \\
\text { would tell us the story of the Trail of Tears? }\end{array}$ & $\begin{array}{l}\text { Who's not telling the story and how might it differ if they } \\
\text { told it? }\end{array}$ \\
\hline $\begin{array}{l}\text { How do you think a descendant of the Cherokee tribe, living today, } \\
\text { would tell the story? }\end{array}$ & $\begin{array}{l}\text { How is this book different than Forced Removal and/or the } \\
\text { textbook? }\end{array}$ \\
\hline What new questions do you have? & Why do you think this information is not in the textbook? \\
\hline \multicolumn{2}{|c|}{ Taking Informed Action } \\
\hline
\end{tabular}

Figure 1. Model Lesson Plan Outline. This figure provides an outline of the main steps and sample critical questions that could be used in a lesson juxtaposing a master and counter narrative.

The model lesson provides teachers with a detailed example of how to juxtapose master and counter narrative picture books using critical literacy questions. In Appendix $\mathrm{A}$ the authors provide a description of paired master and counter narrative picture books that are about historical events often included in elementary social studies standards, along with sample critical questions that could be used with each text. The authors also give a rationale for using each selected pairing to teach critical literacy and historical content from multiple perspectives. The authors' purpose is not to promote specific picture books as the sole texts to use within elementary school social studies, nor do the authors identify a specific grade level to teach the paired texts. Instead, we are demonstrating how master and counter narratives, along with critical questions, can expand the elementary social studies curriculum. It is our goal that readers will critically evaluate the examples to determine their appropriateness for their classroom and then find additional texts to use to implement critical literacy in their own lessons. 


\section{Conclusion}

Elementary social studies is a content area that has been relegated to the sidelines in many schools because of changing educational reform and demands placed upon teachers to focus solely on ELA and mathematics. When elementary school students learn about historical events, they often hear the retelling of a master narrative that focuses on victory and progress from a Eurocentric perspective (VanSledright, 2008). This perpetual reiteration of master narratives silences marginalized voices throughout history and gives students a singular view of the past.

The goal of social studies fosters active citizenship among students who will think critically for the public good of our democracy. Critical literacy provides educators a way to teach elementary school students the skills needed to be informed readers who can critique and question a text for issues of power and equity. The National Council for the Social Studies' C3 Framework dimensions align with critical literacy skills; thus, elementary school teachers can use critical literacy as a way to teach both ELA and social studies standards simultaneously.

In this article the authors have proposed the use of critical literacy in elementary social studies using historical picture books through outlining the purpose of implementation, providing connections between social studies and critical literacy, and sharing examples of paired picture books that could be used in elementary social studies lessons. By juxtaposing master and counter narrative historical picture books, teachers can facilitate critical literacy lessons where students compare multiple perspectives of historical events. This approach allows teachers to integrate literacy and social studies lessons by using critical literacy skills to access social studies content with the goal of fostering informed citizens who seek equity in our society.

\section{References}

Aldridge, D. P. (2006). The limits of master narratives in history textbooks: An analysis of representations of Martin Luther King, Jr. Teachers College Record, 108(4), 662-686. doi:10.1111/j.1467-9620.2006.00664.x.

Berson, M. J. (2009). Harcourt social studies: The United States making a new nation. Orlando, FL: Harcourt, Inc.
Bolgatz, J. (2007). More than Rosa Parks: Critical multicultural social studies in a fourth grade class. Transformations, 18 (1), 39-51.

Brophy, J., \& Alleman, J. (2009). Meaningful social studies for elementary students. Teachers and Teaching, 15(3), 357376. doi:10.1080/13540600903056700.

Brown, A. L., \& Au, W. (2014). Race, memory, and master narratives: A critical essay on U.S. curriculum history. Curriculum Inquiry, 44(3), 358-389. doi:10.1111/curi.12049.

Carney, R. N., \& Levin, J. R. (2002). Pictorial illustrations still improve students' learning from text. Educational Psychology Review, 14(1), 5-26. doi:10.1023/A:1013176309260.

Fuhler, C. J. (1992). The integration of trade books into the social studies curriculum. Middle School Journal, 24(2), 6366. doi:10.1080/00940771.1992.11495173.

Glenn, W. J. (2006). Trusting texts that trust our students: Controversial young adult titles worth teaching. English Journal, 96(2), 88-92. doi:10.2307/30047139.

Giorgis, C. (1999). The power of reading picture books aloud to secondary students. The Clearing House, 73(1), 51-53. doi:10.1080/00098659909599640.

Gross, E. (2009). If I were president: Teaching social justice in the primary classroom. Voices of Practitioners, 10, 1-14.

Heafner, T. L., \& Fitchett, P. G. (2012). Tipping the scales: National trends of declining social studies instructional time in elementary schools. The Journal of Social Studies Research, 36(2), 190-215.

Hibbing, A. N., \& Rankin-Erickson, J. L. (2003). A picture is worth a thousand words: Using visual images to improve comprehension for middle school struggling readers. The Reading Teacher, 56(8), 758-770.

Husband, T. (2012). "I don't see color": Challenging assumptions about discussing race with young children. Early Childhood Education Journal, 39(6), 365-371. doi:10.1007/ s10643-011-0458-9.

Ladson-Billings, G. (1998). Just what is critical race theory and what's it doing in a nice field like education? Qualitative Studies in Education, 11(1), 7-24. doi:10.1080/ 095183998236863.

Loewen, J. W. (2007). Lies my teacher told me: Everything your American history textbook got wrong (2nd ed.). New York, NY: Touchstone.

McDaniel, C. (2004). Critical literacy: A questioning stance and the possiblity for change. The Reading Teacher, 57(5), 472481.

McLaughlin, M., \& DeVoogd, G. (2004). Critical literacy as comprehension: Expanding reader response. International Reading Association, 48(1), 52-62.

Meller, W. B., Richardson, D., \& Hatch, J. A. (2009). Using read-alouds with critical literacy literature in K-3 classrooms. Young Children, 64(6), 76-78.

Mendoza, J., \& Reese, D. (2001). Examining multicultural picture books for the early childhood classroom: Possibilities and pitfalls. Early Childhood Research \& Practice, 3(2), 1-32.

Monforti, J. L., \& McGlynn, A. (2010). Aqui estamos? A survey of Latino portrayal in introductory U.S. government and 
politics textbooks. Political Science \& Politics, 43(2), 309316. doi:10.1017/S1049096510000181.

National Council for the Social Studies. (2013). The college, career, and civil life (C3) framework for social studies state standards: Guidance for enhancing the rigor of $\mathrm{K}-12$ civics, economics, geography, and history. Silver Spring, MD: NCSS.

National Council for the Social Studies. (1994). Expectations for excellence: Curriculum standards for social studies. Washington, DC: National Council for the Social Studies.

O’Neil, K. E. (2011). Reading pictures: Developing visual literacy for greater comprehension. The Reading Teacher, 65(3), 214-223. doi:10.1002/TRTR.01026.

Owens, W. T., \& Nowell, L. S. (2001). More than just pictures: Using picture story books to broaden young learners' social consciousness. The Social Studies, 92(1), 33-40. doi:10.1080/00377990109603973.

Painter, C., Martin, J. R., \& Unsworth, L. (2013). Reading visual narratives: Image analysis of children's picture books. Sheffield, UK: Equinox Publishing.

Rowsell, J., McLean, C., \& Hamilton, M. (2012). Visual literacy as a classroom approach. Journal of Adolescent \& Adult Literacy, 55(5), 444-447. doi:10.1002/ JAAL.00053.

Salinas, C., Blevins, B., \& Sullivan, C. C. (2012). Critical historical thinking: When official narratives collide with other narratives. Multicultural Perspectives, 14(1), 18-27. doi:10.1080/15210960.2012.646640.

Shear, S. (2015). Cultural genocide masked as education: U.S. history textbooks' coverage ofIndigenous education policies. In P. T. Chandler (ed.), Doing race in social studies: Critical perspectives (pp. 13-40). Charlotte, NC: Information Age Publishing.

Souto-Manning, M. (2009). Negotiating culturally responsive pedagogy through multicultural children's literature: Towards critical democratic literacy practices in a first grade classroom. Journal of Early Childhood Literacy, 9(1), 50-74. doi:10.1177/1468798408101105.

Suh, Y., An, S., \& Forest, D. (2014). Immigration, imagined communities, and collective memories of Asian American experiences: A content analysis of Asian American experiences in Virginia U.S. history textbooks. The Journal of Social Studies Research, 39(1), 39-51. doi:10.1016/j. jssr.2014.05.002.

Tsuchiya, Y. (1988). Faithful elephants. I. I. I. T. Lewin Boston, MA: Houghton Mifflin.

Vacca, R. T., \&Vacca, J. L. (2005). Content area reading: Literacy and learning across the curriculum (8th ed.). Boston, MA: Pearson Education.

VanSledright, B. (2008). Narratives of nation-state, historical knowledge, and school history education. Review of Research in Education, 32, 109-146. doi:10.3102/ $0091732 X 07311065$.

Vasquez, V. M. (2010). Getting beyond "I like the book": Creating space for critical literacy in K-6 classrooms (2nd ed.). Newark, DE: International Reading Association.

Wolf, S. A. (2003). Interpreting literature with children. New York, NY: Routledge.

\section{Appendix A}

Paired Picture Book Examples

European Exploration/Invasion

\begin{tabular}{|c|c|}
\hline $\begin{array}{l}\text { Master Narrative With } \\
\text { Sample Critical Questions }\end{array}$ & $\begin{array}{l}\text { Counter Narrative With Sample } \\
\text { Critical Questions }\end{array}$ \\
\hline $\begin{array}{l}\text { Sis, P. (1991). Follow the dream: } \\
\text { The story of Christopher } \\
\text { Columbus. New York, NY: } \\
\text { Alfred A. Knopf Publisher. }\end{array}$ & $\begin{array}{l}\text { Littlechild, G. (1997). This land is my } \\
\text { land. San Francisco, CA: Children's } \\
\text { Book Press. }\end{array}$ \\
\hline $\begin{array}{l}\text { What does the author want us } \\
\text { to think about Christopher } \\
\text { Columbus? }\end{array}$ & $\begin{array}{l}\text { How is this story different from other } \\
\text { stories we have heard about } \\
\text { Christopher Columbus? }\end{array}$ \\
\hline $\begin{array}{l}\text { On the last two pages of the } \\
\text { book, there is a picture } \\
\text { depicting Columbus first } \\
\text { landing in the Americas } \\
\text { and then a picture } \\
\text { depicting a statue of } \\
\text { Columbus today. Why do } \\
\text { you think the illustrator } \\
\text { drew the pictures this way? } \\
\text { What does the illustrator } \\
\text { want you to think about } \\
\text { Christopher Columbus? }\end{array}$ & $\begin{array}{l}\text { Questions after both texts have been } \\
\text { read: }\end{array}$ \\
\hline $\begin{array}{l}\text { Whose story is missing from } \\
\text { this book? }\end{array}$ & $\begin{array}{l}\text { Why do you think the stories about } \\
\text { Christopher Columbus are so } \\
\text { different? } \\
\text { Do you think Christopher Columbus } \\
\text { should be honored with a national } \\
\text { holiday in the United States? Why } \\
\text { or why not? }\end{array}$ \\
\hline
\end{tabular}

In Follow the Dream, Sis (1991) portrays Columbus as a persevering, accomplished explorer while overlooking his role in the injustices against Indigenous Peoples. Littlechild (1997) contrasts this common perspective with that of Indigenous Peoples sharing the pain inflicted on his people through short essays and poems. Juxtaposing these texts encourages students to reflect upon the way in which Columbus is depicted in the social studies curriculum and celebrated nationally, while also encouraging students to examine the discourse of Columbus's "accomplishments" and how it affected those people already occupying the land.

\section{Transcontinental Railroad}

The transcontinental railroad was a major accomplishment in the United States. Floca (2013) depicts this accomplishment in Locomotive, as he describes taking a trip on the new railroad from Omaha to San Francisco. In the book Floca explains what the journey was like and how the steam engine locomotives worked. In contrast, Yin (2001) focuses his book, Coolies, on the labor that was required to build the transcontinental railroad. Coolies recounts the story of two 


\begin{tabular}{lc}
$\begin{array}{l}\text { Floca, B. (2013). Locomotive. New } \\
\text { York, NY: Atheneum Books. }\end{array}$ & $\begin{array}{c}\text { Yin. (2001). Coolies. New York, NY: } \\
\text { Penguin Putnam. }\end{array}$ \\
\hline $\begin{array}{l}\text { Why do you think the } \\
\text { transcontinental railroad is an } \\
\text { important part of the history we } \\
\text { study? }\end{array}$ & $\begin{array}{c}\text { Whose perspective is shared in this } \\
\text { book? Why do you think it was } \\
\text { left out of Locomotive? }\end{array}$ \\
$\begin{array}{l}\text { From whose point of view is the } \\
\text { story told? Whose perspective is }\end{array}$ & $\begin{array}{l}\text { On the page where the Chinese } \\
\text { left out? } \\
\text { laborers are beginning to protest } \\
\text { their rights (pp. 21-22 if self- } \\
\text { counting), ask students: What is } \\
\text { happening in this section? What } \\
\text { do you notice in the picture? Who } \\
\text { has power (authority) in this } \\
\text { situation? } \\
\text { Questions after reading both books: } \\
\text { How do these books compare to the } \\
\text { way the transcontinental railroad } \\
\text { is described in the textbook? } \\
\text { Are workers treated fairly in the U.S. } \\
\text { today? Share why you think yes or } \\
\text { no. }\end{array}$ \\
\hline
\end{tabular}

Chinese brothers who came to the United States to find work. Yin describes the grueling work conditions that railroad laborers faced and the discrimination Chinese workers experienced. Using these books together allows students to not focus solely on the accomplishment of the transcontinental railroad but instead to understand the fuller story of the inequity and difficulties faced by those who labored to create the historical accomplishment.

\section{Immigration}

\begin{tabular}{|c|c|}
\hline $\begin{array}{l}\text { James, H. F. and Loh, V. S. (2013). } \\
\text { Paper son: Lee's journey to } \\
\text { America. Ann Arbor, Ml: Sleeping } \\
\text { Bear Press. }\end{array}$ & $\begin{array}{c}\text { Lainez, R. C. (2010). From north } \\
\text { to south: Del norte al sur. } \\
\text { San Francisco, CA: } \\
\text { Children's Book Press. }\end{array}$ \\
\hline $\begin{array}{l}\text { How do you think Lee's grandparents } \\
\text { felt about him immigrating to the } \\
\text { United States? }\end{array}$ & $\begin{array}{l}\text { Whose perspective is shared in } \\
\text { this story? }\end{array}$ \\
\hline $\begin{array}{l}\text { How do you think this story would be } \\
\text { told from the interrogator's point } \\
\text { of view? }\end{array}$ & $\begin{array}{l}\text { What problems were José's } \\
\text { family facing? Why? }\end{array}$ \\
\hline \multirow{2}{*}{$\begin{array}{l}\text { What feelings do you think you } \\
\text { would have if you left your family } \\
\text { to immigrate to another country } \\
\text { at the age of twelve, as Lee did? }\end{array}$} & $\frac{\text { Questions after reading both }}{\text { books: }}$ \\
\hline & $\begin{array}{l}\text { How are immigration stories } \\
\text { today similar to those from } \\
\text { years ago? } \\
\text { How do these stories help you } \\
\text { understand immigration in } \\
\text { our country today? }\end{array}$ \\
\hline
\end{tabular}

The social studies content regarding immigration in textbooks and standards typically revolves around the early waves of immigrants. For example, Paper Son depicts the experience of a 12-year-old boy immigrating from China to America via Angel Island in 1926.
Yet immigration to the United States continues today. From North to South: Del Norte al Sur portrays an immigrant family that is separated when the mother is deported to Mexico. Juxtaposing these texts aids students in making connections from the past historical time periods to the present.

\section{Holidays}

\begin{tabular}{|c|c|}
\hline $\begin{array}{l}\text { Dalgliesh, A. (1995). The 4th of } \\
\text { July story. New York, NY: } \\
\text { Aladdin Paperbacks. }\end{array}$ & $\begin{array}{l}\text { Johnson, A. (2014). All different now: } \\
\text { Juneteenth, the first day of freedom. } \\
\text { New York, NY: Simon \& Schuster } \\
\text { Books for Young Readers. }\end{array}$ \\
\hline $\begin{array}{l}\text { Whose point of view is the } \\
\text { author sharing in the story? }\end{array}$ & $\begin{array}{l}\text { Whose point of view is the author } \\
\text { sharing in the story? } \\
\text { How does this story help you } \\
\text { understand celebrating } \\
\text { independence better? } \\
\text { Questions after both texts have been } \\
\text { read: } \\
\text { How are these stories of } \\
\text { independence different? Why } \\
\text { are they different? } \\
\text { In The 4th of July Story, there is a } \\
\text { picture of Andrew Jackson } \\
\text { reading the Declaration of } \\
\text { Independence to a group of } \\
\text { people (p. } 22 \text { if self-counting). } \\
\text { Would you draw this picture the } \\
\text { same way? How may you } \\
\text { change it to be more historically } \\
\text { accurate? }\end{array}$ \\
\hline
\end{tabular}

Holidays are a common part of social studies standards in the primary grades, which includes the Fourth of July. Dalgliesh (1995) tells the story of U.S. independence from a mainly Patriot perspective giving an overview of the events leading to the formation of the United States of America. Throughout the book Dalgliesh portrays freedom for all taking place in July 1776. Johnson (2014) describes the story of the last slaves learning of their freedom in Texas when Major General Granger read the Emancipation Proclamation in Galveston, Texas, in 1865. In this book Johnson shares how Juneteenth began as a holiday in the African American community. Using these books together allows students to consider how independence history is told and why some parts of the history is less known.

\section{Picture book references}

Campbell, N. I. (2008). Shin-chi's canoe. Toronto, Ontario: Goundwood Books.

Dalgliesh, A. (1995). The 4th of July story. New York, NY: Aladdin Paperbacks. 
Floca, B. (2013). Locomotive. New York, NY: Atheneum Books. James, H. F., \& Loh, V. S. (2013). Paper son: Lee's journey to America. Ann Arbor, MI: Sleeping Bear Press.

Johnson, A. (2014). All different now: Juneteenth, the first day of freedom. New York, NY: Simon \& Schuster Books for Young Readers.

Lainez, R. C. (2010). From north to south: Del norte al sur. San Francisco, CA: Ok Press: Children's B.
Littlechild, G. (1997). This land is my land. San Francisco, CA: Children's Book Press.

Schwartz, H. E. (2015). Forced removal: Causes and effects of the trail of tears. North Mankato, MN: Capstone Press.

Sis, P. (1991). Follow the dream: The story of Christopher Columbus. New York, NY: Alfred A. Knopf Publisher. Yin. (2001). Coolies. New York, NY: Penguin Putnam. 